\title{
Surgical experience and patient-related restrictions predict the adequacy of cervical mediastinoscopy in non-small cell lung carcinoma lymph node staging
}

Theo J. Klinkenberg ${ }^{1}$, Wobbe Bouma ${ }^{1 *}$, Caroline Van De Wauwer ${ }^{1}$, Rienhart F. E. Wolf ${ }^{1}$, Massimo A. Mariani ${ }^{1}$ and Harry J. M. Groen ${ }^{2}$

\begin{abstract}
Background: Until recently, cervical mediastinoscopy was considered to be the reference standard for mediastinal staging for Non-Small Cell Lung Carcinoma (NSCLC). In the absence of metastases, mediastinal lymph node involvement is the most important prognostic factor and as such it determines therapeutic strategies. In this study we evaluated the adequacy of cervical mediastinoscopy in NSCLC lymph node staging in a large university hospital over more than a decade. In addition, we determined the influence of: (1) surgeon's experience (2) video-assisted mediastinoscopy (VAM) and (3) patient-related restrictions (PRR) on the adequacy of lymph node sampling.

Methods: Between January 2001 and December 2014, 225 patients underwent cervical mediastinoscopy for lymph node staging. Surgical and histological data were reviewed. Thirty-day follow-up was available for all patients. Lymph node sampling was considered adequate when stations $4 \mathrm{~L}, 4 \mathrm{R}$ and 7 were sampled (ESTS guidelines). A surgeon was considered to be experienced when he or she performed at least 40 procedures during the study-period.

Results: Intraoperative mortality was $0 \%$. Thirty-day mortality was $1.3 \%$. Overall adequacy of lymph node sampling was $56 \%$. Univariate and multivariate logistic regression analyses of lymph node sampling adequacy revealed level of surgical experience and PRR as independent predictors of lymph node sampling adequacy.

Conclusions: Surgical experience and PRR independently predict the adequacy of cervical mediastinoscopy in NSCLC lymph node staging. VAM does not independently predict the adequacy of mediastinal lymph node sampling. In light of the expected further decline in mediastinoscopy numbers, we recommend to limit this procedure exclusively to the armamentarium of the experienced thoracic surgeon.
\end{abstract}

Keywords: Mediastinoscopy, Video-assisted mediastinoscopy, Non-small cell lung cancer, Experience

\section{Background}

Lung cancer is the leading cause of cancer death in developed countries and accounts for an estimated $20 \%$ of all cancer deaths [1]. Five-year survival can be achieved in $40-50 \%$ of patients with early stage non-small cell lung carcinoma (NSCLC) [2]. Accurate staging based on tumour size, regional lymph node involvement and presence of metastasis is essential for treatment of NSCLC

\footnotetext{
* Correspondence: w.bouma@umcg.nl

1 Department of Cardiothoracic Surgery, University of Groningen, University

Medical Center Groningen, Groningen, The Netherlands

Full list of author information is available at the end of the article
}

patients [3-5]. In the absence of metastases, mediastinal lymph node involvement is the most important prognostic factor and determines therapeutic strategies; i.e. patients with mediastinal nodal disease will in general not benefit from upfront surgery $[6,7]$.

FluoroDeoxyGlucose - Positron Emission Tomography Computed Tomography (FDG-PET-CT), Endoscopic UltraSound guided-Fine Needle Aspiration and EndoBronchial UltraSound guided-TransBronchial Needle Aspiration (EUS-FNA/EBUS-TBNA) have become the most important techniques in mediastinal lymph node assessment in recent years $[8,9]$. Cervical mediastinoscopy was considered to be

(c) The Author(s). 2018 Open Access This article is distributed under the terms of the Creative Commons Attribution 4.0 International License (http://creativecommons.org/licenses/by/4.0/), which permits unrestricted use, distribution, and 
the reference standard for mediastinal staging of lung cancer. After its introduction in 1957 mediastinoscopy has evolved considerably [10]. Video-assisted mediastinoscopy (VAM) was first reported in literature in 2002 [11] and was introduced at our center in September 2008 and from then on used in each mediastinoscopy case. VAM improved visualization and facilitated teaching tremendously [12]. However, no difference in sensitivity or negative predictive value was found when compared to conventional mediastinoscopy [13]. Nevertheless, the revised ESTS guidelines recommend VAM over conventional mediastinoscopy because of its superior visualization and safety [8].

Mediastinoscopy provides access to the upper paratracheal lymph nodes (stations $2 \mathrm{R}$ and $2 \mathrm{~L}$ ), the lower paratracheal lymph nodes (stations $4 \mathrm{R}$ and $4 \mathrm{~L}$ ) and subcarinal lymph nodes (station 7) $[8,14,15]$. The European Society of Thoracic Surgeons (ESTS) guidelines recommend to acquire at least samples from the lower paratracheal lymph nodes (stations $4 \mathrm{R}$ and $4 \mathrm{~L}$ ) and the subcarinal lymph nodes (station 7) [8]. If present, the upper paratracheal lymph nodes should also be biopsied [8].

A well-executed cervical mediastinoscopy has a sensitivity of $76-85 \%$ and a negative predictive value of $82-92 \%$ [16] with an overall morbidity of $1.07 \%$ and mortality of $0.05 \%$ [17]. It is however important to realize that these values are largely dependent on the level of experience of the surgeon and the extensiveness of lymph node sampling [18]. Therefore, in daily practice, the actual adequacy and reliability of cervical mediastinoscopy is expected to be lower.

In this study we evaluated the adequacy of mediastinal lymph node sampling at our center over more than a decade. In addition, we analyzed the influence of: (1) surgeon's experience, (2) the use of VAM and (3) patientrelated restrictions (PRR) on the adequacy of lymph node sampling (based on the ESTS guidelines).

\section{Methods}

This study was conducted in accordance with the guidelines of the University Medical Center Groningen Institutional Review Board.

\section{Patients}

Between January 2001 and December 2014, 225 patients underwent cervical mediastinoscopy for NSCLC lymph node staging. VAM was introduced at our center in September 2008 and from then on used in each mediastinoscopy case. Patient characteristics are summarized in Table 1. Surgical and histological reports were reviewed. Thirty-day follow-up of survivors was complete and no patient was lost to follow-up.

\section{Adequacy of lymph node sampling}

Based on the ESTS guidelines the minimal requirement for adequate lymph node sampling during cervical
Table 1 Preoperative Patient Data $(n=225)$

\begin{tabular}{|c|c|}
\hline Variable $^{a}$ & Value \\
\hline Age, years & $62.4 \pm 10.1$ \\
\hline \multicolumn{2}{|l|}{ Sex } \\
\hline Male & $167(74)$ \\
\hline Female & $58(26)$ \\
\hline \multicolumn{2}{|l|}{ Histology primary lung tumor } \\
\hline Squamous cell carcinoma & $118(52)$ \\
\hline Adenocarcinoma & $59(26)$ \\
\hline Large cell carcinoma & $45(20)$ \\
\hline Adenosquamous carcinoma & $2(1)$ \\
\hline NSCLC not otherwise specified & $1(0)$ \\
\hline \multicolumn{2}{|l|}{ Clinical N-status } \\
\hline No-1 & $116(52)$ \\
\hline N2 & $100(44)$ \\
\hline N3 & $9(4)$ \\
\hline \multicolumn{2}{|l|}{ Clinical Stage ${ }^{b}$} \\
\hline IA & $5(2)$ \\
\hline $\mathrm{IB}$ & $7(3)$ \\
\hline$\| \mathrm{A}$ & $12(5)$ \\
\hline$\| B$ & $45(20)$ \\
\hline$\| \mathrm{A}$ & $109(48)$ \\
\hline$\| I B$ & $35(16)$ \\
\hline$\| I I C$ & $3(1)$ \\
\hline IVA & $9(4)$ \\
\hline IVB & $0(0)$ \\
\hline \multicolumn{2}{|l|}{ Purpose of cervical mediastinoscopy } \\
\hline Staging & $138(61)$ \\
\hline Staging of tumor with unknown histology & $66(29)$ \\
\hline Restaging after chemotherapy & $20(9)$ \\
\hline Restaging after earlier mediastinoscopy & $1(0)$ \\
\hline Video cervical mediastinoscopy & $187(83)$ \\
\hline \multicolumn{2}{|l|}{ Level of surgeon's experience } \\
\hline Experienced surgeon & $129(57)$ \\
\hline Less experienced surgeon & $96(43)$ \\
\hline
\end{tabular}

${ }^{a}$ Data are presented as mean \pm standard deviation or number (\%) ${ }^{b}$ Based on the 8th edition of the TNM classification for lung cancer (International Association for the Study of Lung Cancer) NSCLC non-small cell lung carcinoma

mediastinoscopy was defined as histologically proven samples from at least the left and right lower paratracheal lymph nodes (station $4 \mathrm{~L}$ and $4 \mathrm{R}$ ) and the subcarinal lymph nodes (station 7) [8].

\section{Level of surgical experience}

The level of surgical experience was based on the number of cervical mediastinoscopies performed by individual surgeons. For surgeons who performed at least 40 
mediastinoscopies during the study-period the adequacy of lymph node sampling was $>70 \%$. Therefore experienced surgeons were defined as those who performed at least 40 mediastinoscopies during the study-period. Based on these criteria two out of sixteen surgeons could be considered experienced. Both experienced surgeons in this study were trained as thoracic surgeons.

\section{Patient-related restrictions (PRR)}

PRR were defined as intraoperative conditions or findings, which complicated the adequacy of lymph node sampling. An overview of PRR is shown in Table 2.

\section{Follow-up}

Follow-up was obtained directly from outpatient visits or by telephone interview with the patient and/or the referring physician. Thirty-day follow-up was complete.

\section{Statistics}

Continuous variables were expressed as mean \pm SD. Categorical variables were expressed as percentages. Comparisons between groups were performed using Pearson's $\mathrm{X}^{2}$

Table 2 Intraoperative and Postoperative Patient Data $(n=225)$

\begin{tabular}{ll}
\hline Variable $^{\text {a }}$ & Value \\
\hline Mean number of sampled lymph node stations (per patient) & $3.5 \pm 1.2$ \\
Mean number of samples taken (per patient) & $11.0 \pm 7.3$ \\
Adequate lymph node sampling & $127(56)$ \\
Based on the ESTS guidelines & $20(8.9)$ \\
Patient-related restrictions & $7(3.1)$ \\
Adhesions & $4(1.8)$ \\
Bleeding, imparing sight & $2(0.9)$ \\
Tumor growth into the mediastinum (inablity to reach & \\
all stations) & $2(0.9)$ \\
Adequate biopsy of very suspicious node (no further & \\
biopsies taken) & $1(0.4)$ \\
Patient habitus & $1(0.4)$ \\
Extremely limited neck mobility & $1(0.4)$ \\
No samples taken on left side due to pre-op hoarseness & $1(0.4)$ \\
Struma & $1(0.4)$ \\
Anomaly of the innominate vein & $0(0)$ \\
Intraoperative mortality & $3(1.3)$ \\
Thirty-day mortality & $7(3.1)$ \\
Post-operative complications & $3(1.3)$ \\
Permanent recurrent laryngeal nerve lesion & $1(0.4)$ \\
Bleeding (causing respiratory insufficiency and intubation) & $1(0.4)$ \\
Pneumonia & $1(0.4)$ \\
\hline & $1(0.4)$ \\
\hline
\end{tabular}

${ }^{a}$ Data are presented as mean \pm standard deviation or number (\%) ESTS European Society of Thoracic Surgeons test or Fisher's exact test as appropriate for categorical variables and the independent samples t-test or MannWhitney $\mathrm{U}$ test, as appropriate for continuous variables. Univariate variables with $P<0.10$ were included in the multivariate analysis. Age and gender were forced in the multivariate model. Multivariate logistic regression analyses by means of a forward stepwise algorithm were performed to identify independent predictors of lymph node sampling adequacy. Odds ratios were reported with 95\% confidence intervals (CI). Goodness-of-fit of the final logistic regression models was assessed with the HosmerLemeshow statistic.

All calculations were performed using a commercially available statistical package (IBM SPSS Statistics 22.0; IBM Corporation, Armonk, NY). Statistically significant differences were defined as $P<0.05$.

\section{Results}

Lymph node sampling adequacy and its predictors based on the ESTS guidelines

The overall adequacy of lymph node sampling was $56 \%$. In patients who underwent cervical mediastinoscopy by an experienced surgeon, adequacy of lymph node sampling was $64 \%$, versus $47 \%$ when operated by a less experienced surgeon $(P=0.013$, Table 3$)$. When PRR occurred, adequacy of lymph node sampling was $20 \%$, versus $60 \%$ when these restrictions did not occur $(P=0.002$, Table 3$)$. The distribution of PRR was not different between patients operated by experienced or less experienced surgeons. PRR did not differ significantly between less experienced and experienced surgeons (PRR 7.8\% vs. 10.4\%, respectively and $P=0.489$ ). Univariate and multivariate logistic regression analyses of lymph node sampling adequacy are shown in Table 3. Multivariate analysis revealed level of surgeon's experience and PRR as independent predictors of lymph node sampling adequacy. The Hosmer-Lemeshow goodness-of-fit test was non-significant, indicating that this multivariate model is a good fit $\left(\mathrm{X}^{2}=0.24, \mathrm{df}=1, P=\right.$ 0.878).

\section{Thirty-day mortality and post-operative complications}

An overview of thirty-day mortality and post-operative complications is provided in Table 2 . Thirty-day mortality was $1.3 \%(n=3)$. All deaths were unrelated to cervical mediastinoscopy. Causes of death included cerebrovascular accident and respiratory insufficiency after partial mandibular resection for a second primary tumour, respiratory insufficiency after thoracotomy and rib resection, and multi-organ failure after early bronchial fistula formation following right-sided pneumonectomy.

\section{Discussion}

This study demonstrates that surgical experience as well as PRR are independent and powerful predictors of the 
Table 3 Predictors of lymph node sampling adequacy by univariate analysis and multivariate logistic regression

\begin{tabular}{|c|c|c|c|c|c|c|}
\hline \multirow[t]{2}{*}{ Variable } & \multicolumn{3}{|c|}{ Univariate analysis } & \multicolumn{3}{|c|}{ Multivariate analysis } \\
\hline & $\mathrm{OR}$ & $95 \% \mathrm{Cl}$ & $P$ value & $\mathrm{OR}$ & $95 \% \mathrm{Cl}$ & $P$ value \\
\hline Age, years & 1.02 & $0.99-1.05$ & 0.141 & - & - & - \\
\hline Female sex & 1.51 & $0.81-2.79$ & 0.192 & - & - & - \\
\hline Squamous cell carcinoma histology & 1.14 & $0.96-1.36$ & 0.147 & - & - & - \\
\hline Video cervical mediastinoscopy & 0.40 & $0.19-0.87$ & 0.021 & - & - & - \\
\hline Experienced surgeon & 1.98 & $1.16-3.39$ & 0.013 & 1.96 & $1.13-3.41$ & 0.017 \\
\hline No patient related restrictions & 6.00 & $1.94-18.59$ & 0.002 & 5.94 & $1.90-18.60$ & 0.002 \\
\hline
\end{tabular}

adequacy of cervical mediastinoscopy in NSCLC lymph node staging. When an experienced surgeons performs the mediastinoscopy adequate lymph node sampling is almost 2 times more likely than when a less experienced surgeon performs the mediastinoscopy (OR 1.96) and when PRR are not present adequate lymph node sampling is almost 6 times more likely than when PRR are present (OR 5.94). Other studies have also shown that mediastinoscopy yield depends strongly on operator skills [18, 19] and lymph node location [20]. The most frequent PRR in this study included adhesions, bleeding (impairing sight), and tumor growth into the mediastinum (inability to reach all lymph node stations). Although PRR did not differ significantly between less experienced and experienced surgeons, one might assume that a more experienced surgeon might be able to overcome certain PRR more easily than a less experienced surgeon. However, our data do not support this assumption. Both surgical experience and PRR proved to be independent predictors in multivariate analysis.

One of the drawbacks of conventional mediastinoscopy is the uncomfortable position for the surgeon. The surgeon has only a narrow view through the instrument and has to find a way among anatomical entities such as; trachea, esophagus, azygos vein, right pulmonary artery, recurrent nerve and pleural space/lung, and depending on patient anatomy; the carotid and innominate arteries. As such, conventional mediastinoscopy is a complex procedure and teaching can also be difficult because of the risk of 'collateral damage'. These events strongly depend on the experience and teaching skills of the surgeon. VAM, with its superior visualization and teaching possibilities, has made the procedure safer and easier to adopt for surgeons in training [21]. In this study the use of VAM was not an independent predictor of adequacy of lymph node sampling, which supports the general observation that the superior visualization with VAM does not lead to a higher quality of mediastinal lymph node sampling compared to conventional mediastinoscopy [13].

Successful treatment of patients with NSCLC strongly depends on strict and reliable staging. The mediastinal lymph node status determines the sequence of treatment modalities. Until recently, mediastinoscopy was the gold standard for invasive mediastinal lymph node staging in NSCLC. Mediastinoscopy provides access to upper paratracheal lymph nodes (stations $2 \mathrm{R}$ and $2 \mathrm{~L}$ ), lower paratracheal lymph nodes (stations $4 \mathrm{R}$ and $4 \mathrm{~L}$ ) and subcarinal lymph nodes (station 7) [14], and has limitations in assessing the posterior subcarinal, lower mediastinal, and hilar lymph nodes [22]. EBUS-TBNA and EUS-FNA have shown to be at least equivalent to mediastinoscopy in sensitivity and negative predictive value [16]. For that reason, and because of the minimally invasive character of these procedures, they are currently recommended to be first choice for invasive mediastinal lymph node staging in lung cancer [8]. EBUS-TBNA and EUS-FNA are safe procedures with minor complications, reported in less than $1 \%$ of cases [23, 24]. Especially the combination of EBUS-TBNA and EUS-FNA allows complete access to nearly all lymph nodes of the mediastinum $[25,26]$. However, pathological assessment of the yield of both procedures is only possible by cytology instead of histology. The samples obtained by needle aspiration are non-diagnostic in a significant number of cases [27] and depend strongly on operator skills [22]. These non-diagnostic cases led to the development of Rapid On-Site Evaluation of the aspirate in order to increase accuracy. This is achieved by monitoring on-site microscopy of repeated lymph node aspirations in different directions of the node until representative samples have been obtained [28].

Limitations of our study include the long time frame and the retrospective design.

Both mediastinoscopy and endosonography are complex technical procedures and depend strongly on operator skills and experience. The complexity of a procedure is inversely related to the adoptability of a procedure [29]. Complexity and adoptability determine the steepness of the learning curve of a procedure and depends on the quantity of procedures performed by the operator. With the growing experience in endosonography, the quantity of mediastinoscopies performed for mediastinal staging in NSCLC is likely to fall back and with it, the adoptability. In this study, we have shown that surgical experience and PRR are key in adequate lymph node sampling. Therefore, 
in light of the expected further decline in mediastinoscopy numbers, we recommend to limit this procedure exclusively to the armamentarium of the experienced thoracic surgeon.

\section{Conclusions}

Surgical experience and PRR are powerful and independent predictors of the adequacy of cervical mediastinoscopy in NSCLC lymph node staging. Experience and skills vary with the training of the operator. Therefore, a solid training is required in educational programs and every center has to look at its own diagnostic yield and negative predictive value. VAM with its superior visualization and teaching possibilities, makes the procedure safer and easier to adopt for surgeons in training, but does not independently predict the adequacy of lymph node sampling. Since mediastinal lymph node staging is crucial in patient treatment and outcome, we urge that cervical mediastinoscopy should be performed and taught by experienced thoracic surgeons only.

\section{Abbreviations}

Ca: Carcinoma; Cl: Confidence interval; EBUS-TBNA: EndoBronchial UltraSound guided-TransBronchial Needle Aspiration; ESTS: European Society of Thoracic Surgeons; EUS-FNA: Endoscopic UltraSound guided-Fine Needle Aspiration; FDG-PET-CT: FluoroDeoxyGlucose - Positron Emission Tomography Computed Tomography; NSCLC: Non-small cell lung carcinoma; PRR: Patientrelated restrictions; SD: Standard deviation; VAM: Video-assisted mediastinocopy

\section{Acknowledgements}

The authors wish to thank Dr. Berenschot and Dr. Papazova for their assistance in data acquisition.

\section{Funding}

This study did not receive any financial support.

\section{Availability of data and materials}

Please contact the corresponding author for data requests.

\section{Authors' contributions}

All authors meet ICMJE guidelines for contribution. TK, WB, and CW collected the data and wrote the manuscript. TK, WB, and HG interpreted statistics. TK, WB, CW, RW, MM, and HG participated in the design of the manuscript and they revised and critically reviewed the manuscript. All authors have read, critically reviewed, and approved the final manuscript.

\section{Ethics approval and consent to participate}

This study was conducted in accordance with the guidelines of the University Medical Center Groningen Institutional Review Board. The need for informed consent was waived due to the retrospective nature of the study.

\section{Consent for publication}

Not applicable.

\section{Competing interests}

The authors declare that they have no competing interests.

\section{Publisher's Note}

Springer Nature remains neutral with regard to jurisdictional claims in published maps and institutional affiliations.

\section{Author details}

'Department of Cardiothoracic Surgery, University of Groningen, University Medical Center Groningen, Groningen, The Netherlands. 'Department of Pulmonary Diseases, University of Groningen, University Medical Center Groningen, Groningen, The Netherlands.
Received: 9 June 2018 Accepted: 13 December 2018

Published online: 29 December 2018

\section{References}

1. Siegel R, Naishadham D, Jemal A. Cancer statistics 2013. CA Cancer J Clin. 2013:63:11-30.

2. Howlader N, Ries LA, Mariotto AB, Reichman ME, Ruhl J, Cronin KA. Improved estimates of cancer-specific survival rates from population-based data. J Natl Cancer Inst. 2010;102:1584-98.

3. Ettinger DS, Wood DE, Akerley W, Bazhenova LA, Borghaei H, Camidge DR, et al. NCCN guidelines insights: non-small cell lung Cancer, version 4, 2016. J Natl Compr Cancer Netw. 2016;14:255-64.

4. Vansteenkiste J, Crinò L, Dooms C, Douillard JY, Faivre-Finn C, Lim E, et al. $2^{\text {nd }}$ ESMO consensus conference on lung Cancer: early-stage non-small cell lung cancer consensus on diagnosis, treatment and follow-up. Ann Oncol. 2014;25:1462-74.

5. Goldstraw P, Crowley J, Chansky K, Giroux DJ, Groome PA, Rami-Porta R, et al. The IASLC Lung Cancer Staging Project: proposals for the revision of the TNM stage groupings in the forthcoming (seventh) edition of the Classification of malignant tumours. International Association for the Study of Lung Cancer International Staging Committee; Participating Institutions. J Thorac Oncol. 2007;2:706-14.

6. Pearson FG, DeLarue NC, Ilves R, Todd TR, Cooper JD. Significance of positive superior mediastinal nodes identified at mediastinoscopy in patients with resectable cancer of the lung. J Thorac Cardiovasc Surg. 1982;83:1-11.

7. Funatsu T, Matsubara Y, Hatakenaka R, Kosaba S, Yasuda Y, Ikeda S. The role of mediastinoscopic biopsy in preoperative assessment of lung cancer. J Thorac Cardiovasc Surg. 1992;104:1688-95.

8. De Leyn P, Dooms C, Kuzdzal J, Lardinois D, Passlick B, Rami-Porta R, et al. Revised ESTS guidelines for preoperative mediastinal lymph node staging for non-small-cell lung cancer. Eur J Cardiothorac Surg. 2014;45:787-98.

9. Sharples LD, Jackson C, Wheaton E, Griffith G, Annema JT, Dooms C, et al. Clinical effectiveness and cost-effectiveness of endobronchial and endoscopic ultrasound relative to surgical staging in potentially resectable lung cancer: results from the ASTER randomised controlled trial. Health Technol Assess. 2012;16:1-75.

10. Carlens E. Mediastinoscopy: a method for inspection and tissue biopsy in the superior mediastinum. Dis Chest. 1959;36:343-52.

11. Hürtgen M, Friedel G, Toomes H, Fritz P. Radical video-assisted mediastinoscopic lymphadenectomy (VAMLA)-technique and first results. Eur J Cardiothorac Surg. 2002:21:348-51.

12. Martin-Ucar AE, Chetty GK, Vaughan R, Waller DA. A prospective audit evaluating the role of video-assisted cervical mediastinoscopy (VAM) as a training tool. Eur J Cardiothorac Surg. 2004;26:393-5.

13. Zakkar M, Tan C, Hunt I. Is video mediastinoscopy a safer and more effective procedure than conventional mediastinoscopy? Interact Cardiovasc Thorac Surg. 2012;14:81-4.

14. Terán MD, Brock MV. Staging lymph node metastases from lung cancer in the mediastinum. J Thorac Dis. 2014;6:230-6.

15. van Albada ME, Eldering MJ, Post WJ, Klinkenberg TJ, Timens W, Groen HJ. The biopsying of at least 5 mediastinal lymph node stations for presurgical staging in patients with a non-small-cell lung carcinoma. Ned Tijdschr Geneeskd. 2004;148(6):281-6.

16. Silvestri GA, Gonzalez AV, Jantz MA, Margolis ML, Gould MK, Tanoue LT, et al. Methods for staging non-small cell lung cancer: diagnosis and management of lung cancer, $3^{\text {rd }}$ ed: American College of Chest Physicians evidence-based clinical practice guidelines. Chest. 2013;143:e211S-50S.

17. Lemaire A, Nikolic I, Petersen T, Haney JC, Toloza EM, Harpole DH Jr, et al. Nine-year single center experience with cervical mediastinoscopy: complications and false negative rate. Ann Thorac Surg. 2006;82:1185-9 discussion 1189-90.

18. Walles T, Friedel G, Stegherr T, Steger V. Learning mediastinoscopy: the need for education, experience and modern techniques-interdependency of the applied technique and surgeon's training level. Interact Cardiovasc Thorac Surg. 2013;16:450-4.

19. Um SW, Kim HK, Jung SH, Han J, Lee KJ, Park HY, et al. Endobronchial ultrasound versus mediastinoscopy for mediastinal nodal staging of nonsmall-cell lung cancer. J Thorac Oncol. 2015;10:331-7.

20. Nelson E, Pape C, Jørgensen OD, Olsen KE, Licht PB. Mediastinal staging for lung cancer: the influence of biopsy volume. Eur J Cardiothorac Surg. 2010;37:26-9. 
21. Lerut T, De Leyn P, Coosemans W, Decaluwé H, Decker G, Nafteux P, et al. Cervical videomediastinoscopy. Thorac Surg Clin. 2010;20:195-206.

22. Harris CL, Toloza EM, Klapman JB, Vignesh S, Rodriguez K, Kaszuba FJ. Minimally invasive mediastinal staging of non-small-cell lung cancer: emphasis on ultrasonography-guided fine-needle aspiration. Cancer Control. 2014;21:15-20

23. Micames CG, McCrory DC, Pavey DA, Jowell PS, Gress FG. Endoscopic ultrasound-guided fine-needle aspiration for non-small cell lung cancer staging: a systemic review and metaanalysis. Chest. 2007;131:539-48.

24. Varela-Lema L, Fernández-Villar A, Ruano-Ravina A. Effectiveness and safety of endobronchial ultrasound-transbronchial needle aspiration: a systematic review. Eur Respir J. 2009;33:1156-64.

25. Hwangbo B, Lee GK, Lee HS, Lim KY, Lee SH, Kim HY, et al. Transbronchial and transesophageal fine-needle aspiration using an ultrasound bronchoscope in mediastinal staging of potentially operable lung cancer. Chest. 2010;138: 795-802.

26. Wallace MB, Pascual JM, Raimondo M, Woodward TA, McComb BL, Crook JE, et al. Minimally invasive endoscopic staging of suspected lung cancer. JAMA. 2008;299:540-6.

27. Whitson BA, Groth SS, Odell DD, Briones EP, Maddaus MA, D'Cunha J, et al True negative predictive value of endobronchial ultrasound in lung cancer: are we being conservative enough? Ann Thorac Surg. 2013;95:1689-94.

28. Nakajima T, Yasufuku K, Saegusa F, Fujiwara T, Sakairi Y, Hiroshima K, et al. Rapid on-site cytologic evaluation during endobronchial ultrasound-guided transbronchial needle aspiration for nodal staging in patients with lung cancer. Ann Thorac Surg. 2013;95:1695-9.

29. Shemin RJ. Surgical lessons learned from the treatment of atrial fibrillation. Heart Rhythm. 2008;5:540-4.

Ready to submit your research? Choose BMC and benefit from:

- fast, convenient online submission

- thorough peer review by experienced researchers in your field

- rapid publication on acceptance

- support for research data, including large and complex data types

- gold Open Access which fosters wider collaboration and increased citations

- maximum visibility for your research: over $100 \mathrm{M}$ website views per year

At $\mathrm{BMC}$, research is always in progress.

Learn more biomedcentral.com/submissions 